\title{
'TigerPaw-NR', a Root-knot Nematode-resistant, Habanero-type Pepper
}

\author{
Richard L. Fery ${ }^{1}$ and Judy A. Thies \\ U.S. Department of Agriculture, Agricultural Research Service, U.S. Vegetable \\ Laboratory, 2700 Savannah Highway, Charleston, SC 29414-5334
}

Additional index words. Capsicum chinense, Meloidogyne, vegetable breeding

'TigerPaw-NR' is a new Habanero-type pepper (Capsicum chinense Jacq.) released 9 Jan. 2006 by the Agricultural Research Service of the U.S. Department of Agriculture (USDA). 'TigerPaw-NR' is homozygous for a dominant gene conditioning a high level of resistance to the southern root-knot nematode [Meloidogyne incognita (Chitwood) Kofoid and White], the peanut root-knot nematode $[M$. arenaria (Neal) Chitwood], and the tropical root-knot nematode [M. javanica (Treub) Chitwood]. Root-knot nematodes are major pests of peppers in the United States, and all Habanero-type cultivars heretofore available to commercial growers and home gardeners are susceptible (Fery and Thies, 1997). The increasing popularity of pungent peppers in the United States has created an intense interest in Habanero-type peppers, and the release of 'TigerPaw-NR' will provide commercial growers and home gardeners access to a root-knot nematoderesistant cultivar.

\section{Origin}

'TigerPaw-NR' is the product of a conventional backcross breeding procedure to transfer the dominant root-knot nematode resistance gene from a Scotch Bonnet accession into a classical Habanero-type background. The donor parent was PA-426 and the recurrent parent was PA-350. PA-426 is a $M$. incognita, $M$. arenaria, and $M$. javanica nematode-resistant, Scotch Bonnet-type germplasm line that was released by the USDA in 1997 (Fery and Thies, 1998b; Thies and Fery, 2001). PA-350, susceptible to root-knot nematodes, is a Habanero-type cultigen obtained from an heirloom collector. 'TigerPaw-NR' was derived from a single $\mathrm{BC}_{4} \mathrm{~F}_{3}$ plant grown in 2002.

\footnotetext{
Received for publication 20 Oct. 2006. Accepted for publication 3 Aug. 2007.

We acknowledge Dr. Paul W. Bosland, Department of Plant \& Environmental Sciences, New Mexico State University, Las Cruces, NM, for assistance in obtaining the pungency determination. The technical assistance of Floyd P. Maguire and Sharon Buckner, ARS-USDA, is also gratefully acknowledged.

${ }^{1}$ To whom reprint requests should be addressed; e-mail Richard.Fery@ars.usda.gov.
}

\section{Description}

'TigerPaw-NR' has a compact plant habit (height $=62 \mathrm{~cm}$, width $=86 \mathrm{~cm}$ ) and produces lantern-shaped, orange-colored fruit. The period from transplanting to first harvest of mature fruit ranges from 77 to $92 \mathrm{~d}$ in Charleston, SC. There are usually two pedicels per axil and the pedicel position at anthesis is intermediate. Flower petal color is white, corolla color is violet, and the stamens have white filaments and purple anthers. At full anthesis, the style is usually the same length or slightly longer than the stamen. The leaves are large and have a lanceolate shape. The stems and leaves are glabrous. There is no visible anthocyanin present on the stems, nodes, branches, petioles, or peduncles. The fruits are attached to the pedicel in a pendant manner (typically one fruit per cluster); the calyx margin shape is dentate; the annular constriction at the junction of the calyx and peduncle is absent; and the pedicels are short, curved, and slender. The fruits are deciduous, i.e., the pedicel and calyx usually remain on the plant at harvest.

The results of three replicated field studies conducted at Charleston, SC, indicate that the fruit characteristics and yield of 'TigerPawNR' are comparable to those of currently available Habanero-type cultivars (Table 1). Marketable yield ranged from $22,352 \mathrm{~kg} \cdot \mathrm{ha}^{-1}$ (four harvest test) to $37,799 \mathrm{~kg} \cdot \mathrm{ha}^{-1}$ (eight harvest test); the average marketable yield for the three studies was $27,555 \mathrm{~kg} \cdot \mathrm{ha}^{-1}$. A typical fruit weighs $7.8 \mathrm{~g}$ and is campanulate or lantern-shaped $(2.7 \mathrm{~cm}$ wide $\times 4.4 \mathrm{~cm}$ long) (Fig. 1). The shape of the peduncle attachment end of the fruit is truncate, the neck at the base of the fruit is absent, and the shape at the blossom end of the fruit is blunt. The fruit cross-section is slightly corrugated. The fruit wall is thin $(1.7 \mathrm{~mm})$. The color of immature fruit is green (Munsell color rating: 5.5 GY $4.8 / 5.3)$; the color of harvest-stage fruit is bright orange (Munsell color rating: 4.1 YR 6.0/9.6). The fruits are extremely pungent (348,634 Scoville heat units), and a typical fruit has three locules (average number of locules $=3.25$ ).

'TigerPaw-NR' is homozygous for a dominant gene that conditions resistance to rootknot nematodes (Fery and Thies, 1998a, 2000). This $C$. chinense resistance gene is allelic to the dominant gene that conditions much of the southern root-knot nematode resistance in the $C$. annuum cv. Carolina Cayenne (Fery and Thies, 1998a). 'Carolina Cayenne' is a highly resistant cultivar whose resistance is derived from the $C$. annuum cayenne-type cultivar Carolina Hot (Fery and Dukes, 1986). Fery and Dukes (1996) reported that the resistance in 'Carolina Hot' is conditioned by two genes, one dominant and one recessive; they demonstrated that the dominant gene in 'Carolina Hot' is allelic to the single dominant gene $(N)$ that conditions the $M$. incognita resistance in the $C$. annuum cv. Mississippi Nemaheart. The $N$ gene was first described in 1957 (Hare, 1957). It needs to be noted that the root-knot nematode resistance exhibited by both 'Carolina Hot' and 'Mississippi Nemaheart' has remained effective for decades; 'Carolina Hot' was

Table 1. Average fruit size and marketable fruit yield of the root-knot nematode-resistant Habanero-type pepper cultivar TigerPaw-NR and the root-knot nematode-susceptible pepper cultivar Habanero grown in three separate trials at Charleston, SC, 2003-2004. ${ }^{\mathrm{z}}$

\begin{tabular}{|c|c|c|}
\hline $\begin{array}{l}\text { Trial/pepper } \\
\text { accession }\end{array}$ & $\begin{array}{l}\text { Fruit size } \\
\text { (g/fruit) }\end{array}$ & $\begin{array}{c}\text { Marketable } \\
\text { fruit yield } \\
\left(\mathrm{kg} \cdot \mathrm{ha}^{-1}\right)\end{array}$ \\
\hline \multicolumn{3}{|l|}{ Trial I } \\
\hline TigerPaw-NR & $8.0 \mathrm{~b}^{\mathrm{y}}$ & $37,799 \mathrm{a}$ \\
\hline Habanero $^{\mathrm{x}}$ & $8.2 \mathrm{a}$ & $35,146 \mathrm{a}$ \\
\hline \multicolumn{3}{|l|}{ Trial II } \\
\hline TigerPaw-NR & $7.7 \mathrm{~b}$ & $22,352 \mathrm{a}$ \\
\hline Habanero & $8.2 \mathrm{a}$ & $21,766 \mathrm{a}$ \\
\hline \multicolumn{3}{|l|}{ Trial III } \\
\hline TigerPaw-NR & $7.6 \mathrm{a}$ & $22,516 \mathrm{a}$ \\
\hline Habanero & $8.0 \mathrm{a}$ & $21,020 \mathrm{a}$ \\
\hline \multicolumn{3}{|c|}{ Combined analysis of all trials } \\
\hline TigerPaw-NR & $7.8 \mathrm{~b}$ NS & 27,555 a NS \\
\hline Habanero & $8.1 \mathrm{a}$ & $25,977 \mathrm{a}$ \\
\hline
\end{tabular}

zThe experimental design of each trial was a randomized complete block with six replications. Trial I was harvested eight times (16 Jul. 20033 Sept. 2003), and Trials II and III were each harvested four times (2 Aug. 2004-1 Sept. 2004 and 12 Aug. 2004-13 Sept. 2004, respectively). ${ }^{y}$ Mean separation within columns and trials by Student-Newman-Keuls multiple range test, $P \leq$ 0.05 .

'Jordan Seeds, Inc., Woodbury, MN.

${ }^{\mathrm{N}}$ Nonsignificant interaction between cultivar and trial at $P \leq 0.05$.

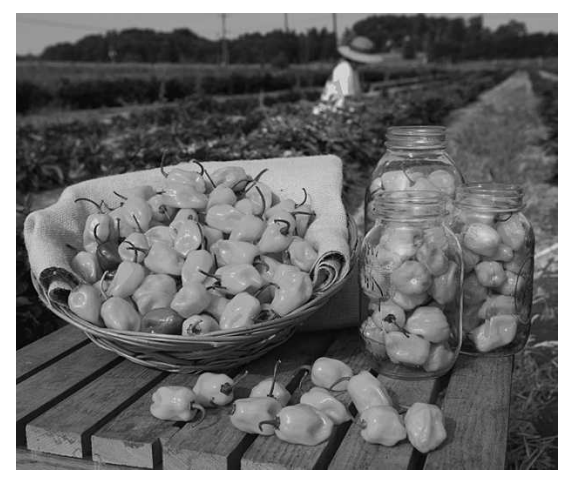

Fig. 1. Typical fruit harvested from the rootknot nematode-resistant Habanero-type cultivar TigerPaw-NR. 
Table 2. Average root-gall index, average egg mass index, and average number of eggs per gram fresh root tissue for PA-426 (Scotch Bonnet-type donor parent of resistance gene), PA-350 (susceptible Habanero-type recurrent parent), and TigerPaw-NR plants grown in soil infested with the southern root-knot nematode, Meloidogyne incognita race 3 (greenhouse experiment). ${ }^{z}$

\begin{tabular}{lccc}
\hline Pepper accession & Gall index & Egg mass index & No. eggs/g fresh root tissue \\
\hline PA-426 & $1.02 \mathrm{~b}^{\mathrm{w}}$ & $1.02 \mathrm{~b}$ & $419 \mathrm{~b}$ \\
PA-350 & $4.51 \mathrm{a}$ & $4.51 \mathrm{a}$ & $25,316 \mathrm{a}$ \\
TigerPaw-NR & $1.09 \mathrm{~b}$ & $1.09 \mathrm{~b}$ & $701 \mathrm{~b}$ \\
\hline
\end{tabular}

${ }^{\mathrm{z}}$ Randomized complete-block experiment with eight replications (five plants per plot; seeds planted on 27 Feb. 2004; seedlings transplanted into a steam-pasteurized mixture of soil, sand, and peat on 17 Mar. 2004; soil surrounding roots of each seedling was infested with $3000 \mathrm{M}$. incognita race 3 eggs on 9 Apr. 2004; and roots of all plants removed from the growth media on 7 Jun. 2004 for evaluation for galling and egg masses). The $\mathrm{NaOCl}$ procedure described by Hussey and Barker (1973) was used to extract M. incognita eggs from a fibrous root sample taken from each plot.

${ }^{y}$ Rated on a scale of 1 to $5: 1=$ no galls; $2=$ light galling, $1 \%$ to $25 \%$ of root system galled; $3=$ moderate galling, $26 \%$ to $50 \%$ of root system galled; 4 = heavy galling, $51 \%$ to $80 \%$ of root system galled; and $5=$ severe galling, $81 \%$ to $100 \%$ of root system galled.

${ }^{x}$ Rated on a scale of 1 to $5: 1=$ no egg masses evident, 2 = scattered egg masses covering $1 \%$ to $25 \%$ of root system, 3 = moderate number of egg masses covering $26 \%$ to $50 \%$ of root system, $4=$ numerous egg masses covering $51 \%$ to $80 \%$ of root system, and $5=$ extremely large number of egg masses covering $81 \%$ to $100 \%$ of root system.

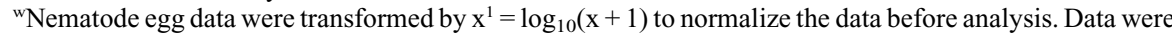
analyzed using the GLM procedure of SAS (SAS Institute, Cary, NC) and means were separated using Duncan's multiple range test, $P \leq 0.05$.

released in the late 1950s (Martin and Crawford, 1958) and 'Mississippi Nemaheart' was released in the mid-1960s (Hare, 1966).

The new cultivar has exhibited a high level of resistance to the southern root-knot nematode in all greenhouse tests; the numbers of galls and egg masses on the roots have always been minimal. The results of an eight-replicate test conducted in greenhouse soil benches infested with $M$. incognita race 3 showed that 'TigerPaw-NR' roots yielded $97 \%$ fewer $M$. incognita eggs per $\mathrm{g}$ fresh root than did roots of the susceptible recurrent parent $P A-350$ (Table 2). The resistance exhibited by 'TigerPaw-NR' is equal to that exhibited by the donor of the resistant gene, $P A-426$.

The root-knot nematode-resistant 'TigerPaw-NR' is recommended for use by both commercial growers and home gardeners. It requested that appropriate recognition of source be given when this germplasm contributes to research or development of a new breeding line or cultivar.

\section{Literature Cited}

Fery, R.L. and P.D. Dukes. 1986. 'Carolina Cayenne' pepper. HortScience 21:330.

Fery, R.L. and P.D. Dukes. 1996. The inheritance of resistance to the southern root-knot nematode in 'Carolina Hot' cayenne pepper. J. Amer. Soc. Hort. Sci. 121:1024-1027.

Fery, R.L. and J.A. Thies. 1997. Evaluation of Capsicum chinense Jacq. cultigens for resistance to the southern root-knot nematode. HortScience 32:923-926.

Fery, R.L. and J.A. Thies. 1998a. Genetic analysis of resistance to the southern root-knot nematode in Capsicum chinense Jacq. J. Amer. Soc. Hort. Sci. 123:1008-1011.

Fery, R.L. and J.A. Thies. 1998b. PA-353, PA-398, and PA-426: Southern root-knot nematoderesistant Capsicum chinense Jacq. germplasm lines. HortScience 33:760-761.

Fery, R.L. and J.A. Thies. 2000. Inheritance of resistance to the peanut root-knot nematode in Capsicum chinense. J. Amer. Soc. Hort. Sci. 125:615-618.

Hare, W.W. 1957. Inheritance of resistance to rootknot nematodes in pepper. Phytopathology 47 : 455-459.

Hare, W.W. 1966. New pimiento is resistant to nematodes. Mississippi Farm Res. 29(2):1, 8.

Hussey, R.S. and K.R. Barker. 1973. A comparison of methods of collecting inocula of Meloidogyne spp., including a new technique. Plant Dis. Rptr. 57:1025-1028.

Protection for 'TigerPaw-NR' is being sought under the Plant Variety Protection Act. Genetic material of this release will be deposited in the National Plant Germplasm System where it will be available for research purposes, including the development and commercialization of new cultivars. It is
Martin, J.A. and J.H. Crawford. 1958. Carolina Hot pepper. South Carolina Agr. Expt. Sta. Circ. 117.

Thies, J.A. and R.L. Fery. 2001. Characterization of Capsicum chinense cultigens for resistance to Meloidogyne arenaria, M. hapla, and M. javanica. Plant Dis. 85:267-270. 